\title{
Correction to: Influence of soil properties on the heartwood colour of Juglans mandshurica var. sachalinensis in a cool temperate forest
}

Kobayashi Makoto ${ }^{1 * \dagger}\left(\mathbb{0}\right.$, Elizaveta Susloparova ${ }^{2 \dagger}$, Ikutaro Tsuyama ${ }^{3}$, Takuya Shimase ${ }^{3}$, Satoshi Nakaba ${ }^{4}$, Naoki Takahashi ${ }^{5}$ and Toshiya Yoshida ${ }^{6}$

\section{Correction to: J Wood Sci (2021) 67:49}

http://doi.org/10.1186/s10086-021-01981-9

In the original publication of the article [1], the 10th line in the abstract should read as "Higher soil Mg contents resulted in increased greenness.......... The second sentence in the "Results and discussion" section should read as "High soil Mg contents resulted in more greenish heartwood in J. mandshurica var. sachalinensis (Fig. 1a). The original article has been corrected.

\section{Author details}

${ }^{1}$ Teshio Experimental Forest, Field Science Center for Northern Biosphere, Hokkaido University, Horonobe, Hokkaido 098-2943, Japan. ${ }^{2}$ Institute of Geology and Nature Management, Far Eastern Branch, Russian Academy of Sciences, Blagoveshchensk 675000, Russia. ${ }^{3}$ Hokkaido Research Center, Forestry and Forest Products Research Institute, 7 Hitsujigaoka, Toyohira-ku, Sapporo, Hokkaido 062-8516, Japan. ${ }^{4}$ Faculty of Agriculture, Tokyo University of Agriculture and Technology, 3-5-8 Saiwai-cho, Fuchu, Tokyo 183-8509, Japan. ${ }^{5}$ Division of Industrial Promotion, Town Office of Nakagawa Town, Nakagawa, Hokkaido 098-2802, Japan. ${ }^{6}$ Field Science Center for Northern Biosphere, Hokkaido University, Nayoro, Hokkaido 096-0071, Japan.

Accepted: 24 November 2021

Published online: 07 December 2021

\section{Reference}

1. Makoto K, Susloparova E, Tsuyama I, Shimase T, Nakaba S, Takahashi N, Yoshida T (2021) Influence of soil properties on the heartwood colour of Juglans mandshurica var. sachalinensis in a cool temperate forest. J Wood Sci 67:49. https://doi.org/10.1186/s10086-021-01981-9

\section{Publisher's Note}

Springer Nature remains neutral with regard to jurisdictional claims in published maps and institutional affiliations.

*Correspondence: makoto@fsc.hokudai.ac.jp

${ }^{\dagger}$ Kobayashi Makoto and Elizaveta Susloparova contributed equally to this manuscript

${ }^{1}$ Teshio Experimental Forest, Field Science Center for Northern Biosphere,

Hokkaido University, Horonobe, Hokkaido 098-2943, Japan

Full list of author information is available at the end of the article

(c) The Author(s) 2021. Open Access This article is licensed under a Creative Commons Attribution 4.0 International License, which permits use, sharing, adaptation, distribution and reproduction in any medium or format, as long as you give appropriate credit to the original author(s) and the source, provide a link to the Creative Commons licence, and indicate if changes were made. The images or other third party material in this article are included in the article's Creative Commons licence, unless indicated otherwise in a credit line to the material. If material is not included in the article's Creative Commons licence and your intended use is not permitted by statutory regulation or exceeds the permitted use, you will need to obtain permission directly from the copyright holder. To view a copy of this licence, visit http://creativecommons.org/licenses/by/4.0/. 